\title{
New reports of the Argentine ant Linepithema humile (Mayr, 1868) (Hymenoptera: Formicidae) in Algeria
}

\author{
S. Slimani ${ }^{1}$, H. Berrai ${ }^{1}$, R. Meridji ${ }^{1}$, A. Taheri ${ }^{2}$, L. Dahmani ${ }^{1}$, A. Chebli ${ }^{1}$, M. Biche ${ }^{1}$ \\ ${ }^{1}$ Department of Agricultural and Forestry Zoology, National School of Agronomy, El-Harrach, Algeria \\ ${ }^{2}$ Department de Biologie, Faculté des Sciences, Universite Chouaïb Doukkali, BP 20, El-Jadida 24000, Maroc
}

*Corresponding author E-mail: mohammedbiche@gmail.com; m. biche@ensa.dz

Received: 05.10.2020. Accepted 05.11.2020

\begin{abstract}
The species was firstly reported in 1923 by Cagniant without précising the localization. It was only in 2015 that Barech et al., rediscovered this ant around Melbou in the locality of Bejaia (Algeria). This study is conducted within the framework of a project of $\mathrm{PhD}$ on myrmécologique wildlife Algeria. During our investigations across the national territory, we were able to collect specimens of the Argentine ant, Linepithema humile (Mayr, 1868). The species has been recently collected from 5 localities in the coast from Algiers to Jijel and 1 signalization has been done in the town of Tizi Gheniff (Province of Tizi Ouzou, 90 km East of Algiers).
\end{abstract}

Keywords: Linepithema humile; Formicidae; Rediscovery; Algeria

\section{Introduction}

Invasive alien species are recognized as the second cause of global biodiversity loss (Sax \& Gaines, 2008). According to the latest red list's assessment from the International Union for Conservation of Nature (IUCN), they are a menace to nearly a third of threatened terrestrial species and are involved in half of known extinctions. In island environments, they are the primary cause and engender profound changes within these ecosystems (Courchamp et al., 2003). The development of human activities has intensified these natural mechanisms of invasion. Their number, frequency and distance travelled during these "natural biological invasions" were negligible compared to the invasions currently caused by international trade and transport (Mack et al., 2000). Global human trade and transportation have greatly increased the ability of many species to settle in regions outside their natural distribution areas (Drake et al., 1989; Mooney \& Drake, 1989; Williams, 1994; Sandland et al., 1999; Floerl \& Inglis, 2004).

According to Blard (2006), ants are among the most devastating. For this, exotic ant species are currently receiving considerable attention worldwide, reflecting their growing economic and agricultural impact, their effects on human health, in addition to native species' displacement and natural ecosystems disruption (Ward et al., 2006). Ants play an important role in the ecosystems' functioning due to their enormous numbers (Wilson, 1987). Over 200 ants' species are classified as invaders causing the most harmful consequences in the areas where they were introduced (Holway et al., 2002). An expanded list presented by Wetterer (2015) includes 42 species of cosmopolitan ants. In Algeria, fourteen species are the main pests for ecological, agricultural and / or household products (Ousalah et al., 2019): Anoplolepis gracilipes (Smith, 1857), L. humile (Mayr, 1868), Monomorium pharaonis (Linnaeus, 1758), Nylanderia bourbonica (Forel, 1886), N. jaegerskioeldi (Mayr, 1904), Paratrechina longicornis (Latreille, 1802), Pheidole megacephala (Fabricius, 1793), Solenopsis geminata (Fabricius, 1804), Solenopsis invicta (Buren, 1972) Tapinoma melanocephalum (Fabricius, 1793), Technomyrmex difficilis (Forel, 1892), destructeur de Trichomyrmex destructor (Jerdon, 1851) et Wasmannia auropunctata (Roger, 1863). Among all these ants, the Argentine ant L. humile although it is native to South America, it has become a cosmopolitan pest, especially in the Mediterranean climates of North America, Chile, South Africa, Australia, and Southern Europe (Suarez et al. 2001). A species mainly present in hot and humid anthropogenic environments on the Mediterranean coast, it does not tolerate low temperatures and it is therefore never found at altitude (Lebas et al., 2016). Outside the Mediterranean region, this species can take over heated spaces such as greenhouses and garden centers (Galkowski, 2008). Its invasiveness is so important that it is cited on the list of the 100 species (animals and plants) the most invasive in the world by the International Union for Conservation of Nature (Lowe et al., 2000). This invasion causes the eradication of native ant species (Cammell et al., 1996; Human et Gordon, 1996; Abril et Gomez, 2011). As a result, the spread and impact of L. humile has received a lot of attention, where it is described as a major pest, a real scourge in the United States and Europe (Human \& Gordon, 1997; Wetterer et al., 2006).

L. humile has negative impacts on many animals, both vertebrates and invertebrates (Wetterer et al., 2001). By the diversity of their mores, their social organization and their specialized behaviours, the ants manage to occupy distinct ecological niches within many terrestrial ecosystems (Hölldobler \& Wilson, 1994). Nest density can be significant. Each nest can contain more than a hundred queens and thousands of workers (Lebas et al., 2016). It forms very populous and very active colonies which can cause damage to the plantations. Colonies expansion takes place at the expense of extinct native species (Galkowski, 2008). Its noxiousness is also reported in horticultural crops (Lester et al., 2003). The myrmecofauna of Algeria remains not very well known, more particularly exotic ants. Where research on these latter, is very rare or even non-existent. In Algeria, the habitats diversity is very noticeable which are influenced by the diversity of ecosystems and climate as well as accelerated urbanization, which promotes the invasion of these ants. Within the framework of our project on the myrmecofauna of Algeria, an inventory is carried out on all the Algerian territory which aims to map the data of our inventory and the update of the myrmecological fauna. Therefore, detailed 
knowledge and detection of exotic species is useful for preventive management of potential invaders. Each case deserves, certainly, its own attention, as it is difficult to agree on the general rules applicable to potential invaders. On the other hand, to draw the attention of the plant protection services and the biodiversity conservation organizations in Algeria to this scourge which can grow as it goes along.

In 1923, L. humile was found in Algeria by Frisque (1935) without giving any information on the localities where it was found. Its presence was not confirmed by Bernard or Cagniant during their research. It was rediscovered by Barech in 2010 in the North-East of the country in the region of Melbou (Béjaia) in a publication published in (2015).

\section{Materials and Methods}

Sampling was carried out in different agricultural ecosystems in urban areas throughout the Algerian territory. Two sampling methods were carried out in the field; sight hunting and Pitfalls. Sight hunts were carried out randomly using a mouth vacuum cleaner on trees, under stones, in the form of single individuals or in nests. Sight hunts were carried out randomly using an insect mouth vacuum (aspirator) on trees, under stones, in the form of single individuals or in nests. The myrmecofauna trapping by pitfalls consists on burying 10 pots in the ground, placed in line and separated by a 5 meter interval. The pot upper edge is at the level of the ground surface. They are filled with soaped water up to a third of the height for a period of 48 hours. The sampling of the inventory in the field takes into account, the type of environment and the main plant species, as well as the GPS coordinates and the date, which were noted for each location.

Table 1. Ants' sampling sites.

\begin{tabular}{|c|c|c|c|c|c|}
\hline Locality & Date & Latitude & Longitude & Altitude & Ecosystem \\
\hline $\begin{array}{l}\text { ENSA El-Harrach } \\
\text { (Algiers) }\end{array}$ & Jul-19 & $36^{\circ} 43^{\prime} 19.70^{\prime \prime} \mathrm{N}$ & $03^{\circ} 08^{\prime} 55.19 " \mathrm{E}$ & $47 \mathrm{~m}$ & $\begin{array}{l}\text { Park - Under } \\
\text { stones }(\mathrm{H})\end{array}$ \\
\hline $\begin{array}{l}\text { H'raoua - } \quad \text { Ain } \\
\text { Taya (Algiers) }\end{array}$ & Aug-19 & $36^{\circ} 46^{\prime} 47.92^{\prime \prime} \mathrm{N}$ & $03^{\circ} 17^{\prime} 40.79^{\prime \prime E}$ & $2 \mathrm{~m}$ & \multirow{2}{*}{$\begin{array}{l}\text { Market gardening } \\
\text { (H) }\end{array}$} \\
\hline $\begin{array}{l}\text { Zemmouri } \\
\text { (Boumerdes) }\end{array}$ & Aug-19 & $36^{\circ} 47^{\prime} 06.83^{\prime \prime} \mathrm{N}$ & $03^{\circ} 35^{\prime} 51.87^{\prime \prime} \mathrm{E}$ & $73 \mathrm{~m}$ & \\
\hline Rouiba (Algiers) & Jul-19 & $36^{\circ} 44^{\prime} 24.41^{\prime \prime} \mathrm{N}$ & $03^{\circ} 17^{\prime} 54.91^{\prime \prime} \mathrm{E}$ & $15 \mathrm{~m}$ & $\begin{array}{l}\text { Citrus Orchard } \\
\text { (H) }\end{array}$ \\
\hline $\begin{array}{l}\text { Tizi Ghennif (Tizi } \\
\text { Ouzou) }\end{array}$ & Jul-19 & $36^{\circ} 35^{\prime} 23.47^{\prime \prime N}$ & $03^{\circ} 46^{\prime} 16.96 " \mathrm{E}$ & $356 \mathrm{~m}$ & $\begin{array}{l}\text { Market gardening } \\
\text { (H) }\end{array}$ \\
\hline $\begin{array}{l}\text { Sidi } \\
\text { (Jijel) }\end{array}$ & Aug-19 & $36^{\circ} 51^{\prime 23.31 " N}$ & $6^{\circ} 03^{\prime} 36.01 \mathrm{E}$ & $14 \mathrm{~m}$ & Road \\
\hline Melbou (Bejaia) & & & & & \\
\hline Barech et al., 2015 & Aug-10 & $36^{\circ} 38^{\prime} 34.00^{\prime \prime} \mathrm{N}$ & $05^{\circ} 22^{\prime} 07^{\prime \prime} \mathrm{E}$ & $4 m$ & Beach \\
\hline
\end{tabular}

\section{H: Humid.}
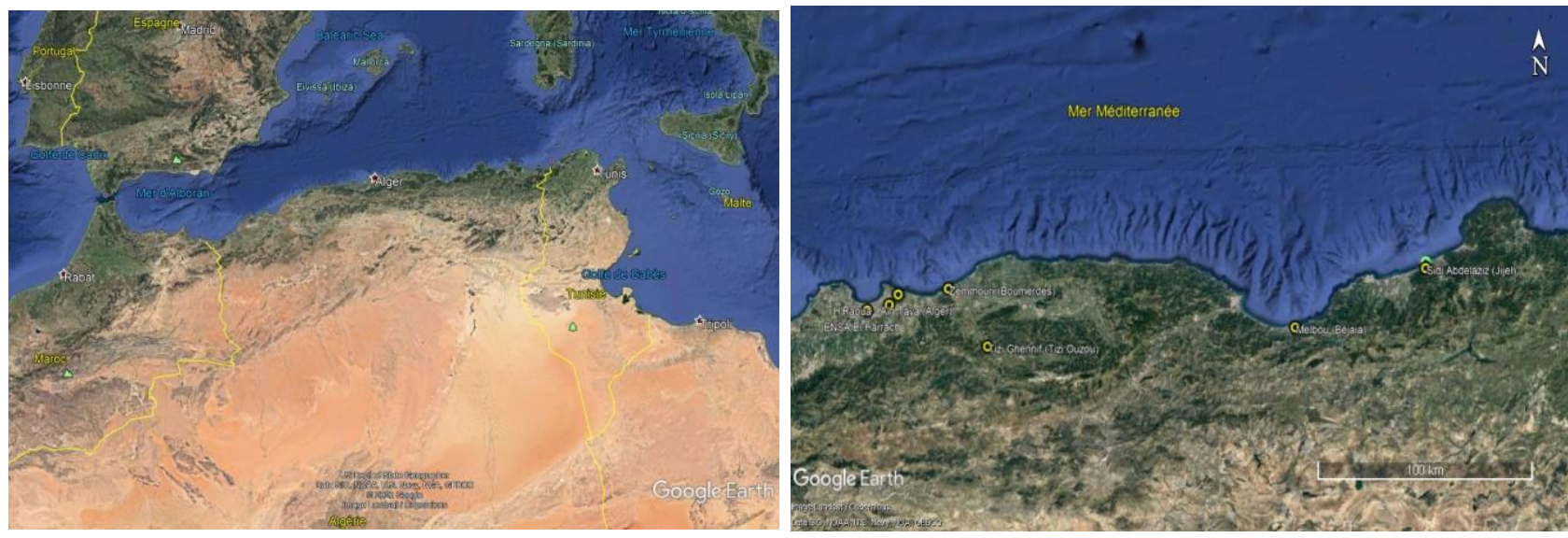

Figure 1. Geographical location of L. humile collection sites. 


\section{Results and Discussion}

The Argentine ant Linepithema humile (MAYR, 1868) originates from subtropical South America, is a major pest in many regions of the world with a Mediterranean climate (Witterer et al., 2009). Compared to Tapinoma et Lasius, L. humile workers are particularly recognizable by a uniformly brown body with long antennae inserted just on the upper edge of the clypeus and developed eyes (Figure 1) with a marked meso-propodeal groove (Figure 2). The back of the head, mesosoma, petiole and abdominal tergites 3 and 4 deprived of upright bristles (Wild, 2004). The specimens are deposited at the Department of Agricultural and Forestry Zoology of the National School of Agronomy (El-Harrach - Algiers).
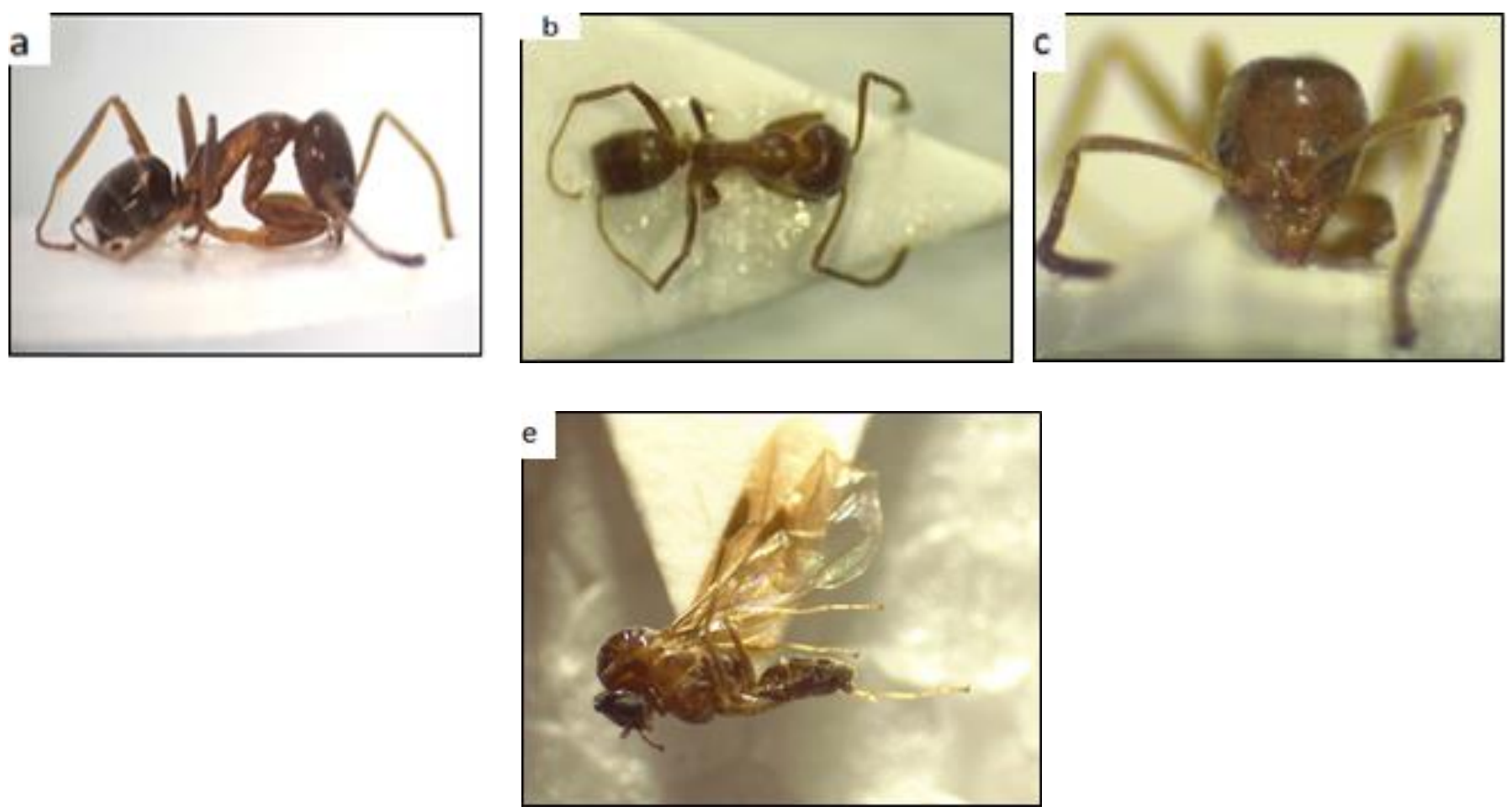

Figure 2. Linepithema humile: a) Worker in profile view, b) Dorsal view, c) Head, e) Male.

By analyzing the data, we have so far encountered L. humile in 6 new sites in Algeria (Table 1) at different altitudes ranging from 7 $\mathrm{m}$ (Coastline) to $356 \mathrm{~m}$ (sub-coast) belonging to the humid bioclimatic stage with mild winter (Algiers, Rouiba, Zemmouri, Jijel) to the sub-humid with cold winter (Tizi ouzou). All individuals are found in association with Tapinoma sp in urban areas under stones but also in citrus orchards (Citrus lemon and C. sinensis) and vegetable crops in open fields (tomatoes, pepper).

Just as stated by Barech et al., (2015), this species seems to be like a real invader or as a vagabond species (tramp species) in these new collection sites in Algeria. This could have a certain impact on biodiversity. In fact, Soubeyran (2008) notes that invasive ants have the ability to attack many native or endemic invertebrates' species or small vertebrates and can affect the whole functioning of an ecosystem. It is accepted that the Argentine ants seem to be well established in their area of introduction (Blight et al., 2009). Harris (2002), reports that these ants are also able to relocate and survive in response to high levels of disturbance. Although Bernard (1956) et Monnin et al. (2013) say that L. humile does not go far from the coast and does not penetrate more than a few tens of kilometres in the ground because it tolerates drought very badly, we found it in the interior of the country in Tizi Gheniff region (located at $370 \mathrm{~m}$ above sea level) in a sublittoral bioclimatic stage with mild winter. In this region, the summers are short, very hot, dry and mostly clear. While, the winters are long, chilly, precipitation and partly cloudy. During the year, the temperature generally varies from $2{ }^{\circ} \mathrm{C}$ to $32^{\circ} \mathrm{C}$ and is rarely below $-2^{\circ} \mathrm{C}$ or above $36^{\circ} \mathrm{C}$. If $\mathrm{L}$. humile seems unable to extend its territory more widely, it may be because of another Dolichoderinae, Tapinoma simrothi which repels it victoriously as it is the case in Tangier (Cagniant, 1962) and in Corsica (Casevitz-Weulersse, 1991). Since the ant is recognized as an invasive species, the Algerian plant protection services, in collaboration with the EPPO (European and Mediterranean Plant Protection Organization) insert $L$. humile in the list of quarantined harmful animal species, and prohibit their introduction to Algeria. Law No. 84 of December 29 , 2004, published on the official journal of the Republic of Algeria, reinforced this initiative as part of a cooperation agreement between the Algerian and Turkish governments, in the fields of phytosanitary quarantine and plant protection.

\section{Conclusion}

The current study has allowed us to confirm once again the presence of the Argentine ant in new colonization sites. These sites which host this ant, can be a certain danger for diversity. It would therefore be very interesting to take a very serious look at the colonization of sites by this ant and other invasive species and to measure the impact that these species can cause on other native species.

\section{References}

Abril, S., \& Gomez, C. (2011). Aggressive behaviour of the two european argentine ant supercolonies (Hymenoptera: Formicidae) towards displaced native ant species of the northeastern iberian peninsula. Myrmecological news, 14, 99106. 
Barech, G., Rebbas, K., Khaldi, M., Doumandji, S., \& Espadaler X. (2015). Redécouverte de la fourmi d'argentine Linepithema humile (Hymenoptera: Formicidae) en Algérie: un fleau qui peut menacer la biodiversité. Boletín de la Sociedad Entomológica Aragonesa (s.e.a.), 56: 269-272.

Bernard, F. (1956). Remarques sur le peuplement des Baléares en fourmis. Bulletin de la Société d'Histoire Naturelle de l'Afrique du Nord, 47: 254 -266.

Blard, F. (2006). Les fourmis envahissantes de l'ile de la réunion: interactions compétitives et facteurs d'invasion. Thèse de doctorat, Université de la réunion, St Denis, France, $97 \mathrm{pp}$.

Blight, O., Orgeas, J., Renucci, M. A., Tirard, A., \& Provost. E. (2009). Where and how Argentine ant (Linepithema humile) spreads in Corsica? Comptes Rendus Biologies, 332: 747-751.

Cagniant, H. (1962). Etude de quelques fourmis marocaines: Statistiques provisoires des Formicidae du Maroc. Bulletin Société d'Histoire Naturelle d'Afrique du Nord, 53: 83-118.

Cammell, M. E.; Way, M. J., \& Paiva M. R. (1996). Diversity and structure of ant communities associated with oak, pine, eucalyptus and arable habitats in Portugal. Insectes Sociaux, 43, 37-46.

Casevitz-Weulersse, J. (1991). Les Fourmis de Corse. Insectes, 81: 2-4.

Courchamp, F., Chapuis, J. L., \& Pascal, M. (2003). Mammal invaders on islands: impact, control and control impact. Biol. rev., 78: 347-383.

Frisque, K. (1935). La fourmi d'Argentine Iridomyrmex humilis Mayr dans les serres en Belgique. Annales de la société entomologique de Belgique, 75: 148-153.

Galkowski, C. (2008). Quelques fourmis nouvelles ou intéressantes pour la faune de France (Hymenoptera, Formicidae). Bulletin de la Société Linnéenne de Bordeaux, (n.s.), 143 (36): 423-433.

Harris, R. J. (2002). Potential impact of the Argentine ant (Linepithema humile) in New Zealand and options for its control. Ed. department of conservation, Wellington, New Zealand, $36 \mathrm{p}$.

Hölldobler, B., \& Wilson, E. O. (1990). The ants. Harvard University Press, Cambridge, 732 pp.

Holway, D.A., Suarez, A.V., \& Case T. J. (2002). Role of abiotic factors in governing susceptibility to invasion: a test with Argentine ants. Ecology, 83, 1610-1619.

Human, K.G., \& Gordon, D. M. (1996). Exploitation and interference competition between the invasive Argentine ant Linepithema humile and native ant species. Oecologia, 105, 405-412.

Lebas, C., Galkowski, C., Blatrix, R., \& Wegnez, P. (2016). Fourmis d'Europe occidentale. Ed. Delachaux et Niestlé, Paris, $415 p$

Lester, P. J., Baring, C. W., Longson, C. G., Hartley, S. (2003). Argentine and other ants (Hymenoptera: Formicidae) in New Zealand horticultural ecosystems: distribution, hemipteran hosts, and review. New Zealand entomologist, 26: 7989.

Lowe, S., Browne, M., Boudjelas, S., \& De Poorter, M. (2000). 100 of the World's Worst Invasive Alien Species. A Selection from the Global Invasive Species Database. The Invasive Species Specialist Group (ISSG), 12 p.

Mc Glynn, T.P. (1999). The worldwide transfer of ants: Geographical distribution and ecological invasions. Journal of biogeography, 26: 535-548.

Miravete, V., Roura-Pascual, N., Dunn, R. R., \& Gómez, C. ( 2013). How many and which ant species are being accidentally moved around the world? Biology letters, 9: 20130540.

Monnin, T., Espadaler, X., Lenoir, A., \& Peeters, C. (2013). Guide des fourmis de France. Edition Belin, Baume-LesDames, 156 pp. OEPP, (2000). Résumés de I'Organisation Européenne et Méditerranéenne pour la Protection des Plantes. Réglementation phytosanitaire. Paris, $22 \mathrm{p}$.

Ousalah, N., Marniche, F., Espadaler, X., \& Biche, M. (2019). Exotic ants from the Maghreb (Hymenoptera, Formicidae) with first report of the hairy alien ant Nylanderia jaegerskioeldi (Mayr) in Algeria. Arxius de miscel lània zoològica, 17: 45-58

Sarnat, E.M., Fischer, G., Guénard, B., Economo, E. P. (2015). Introduced pheidole of the world: taxonomy, biology and distribution. Zookeys, 533: 1-109.

Sarnat, R. M., Suarez, A., \& Ficher, B. (2016). Antweb.org. https://www.antweb.org/project.do?name=introduced ants. Sax, D. F., \& Gaines, S. D. (2008). Species invasions and extinction: the future of native biodiversity on islands. Proc. Nat. Acad. Sci., USA, 105: 11490-11497.

Soubeyran, Y. (2008.). Espèces exotiques envahissantes dans les collectivités françaises d'outre-mer. Etat des lieux et recommandations. Collection Planète Nature. Comité français de I'UICN, Paris, 202 pp.

Suarez, A. V., Holway, D. A., \& Case, T. J. (2001). Patterns of spread in biological invasions dominated by longdistance jump dispersal: insights from argentine ants. Proceedings of the National Academy of sciences of the United States of America, 98: 1095-1100.

Ward, D. F., Beggs, J. R., Clout, M. N., Harris, R. J., \& O'conor, S. (2006). The diversity and origin of exotic ants arriving in New Zealand via human-mediated dispersal. Diversity and distributions 12: 601-609.

Wetterer, J. K., \& Garcia, F. H. (2015). Worldwide spread of Tetramorium caldarium (Hymenoptera: Formicidae). Myrmecological News, 21: 93-99.

Wetterer, J. K., Wetterer, A. L., \& Hebard, E. (2001). Impact of the argentine ant, Linepithema humile on the native ants of Santa Cruz Island, California. Sociobiology, 38: 709-721.

Wetterer, J. K., Espadaler, X., Wetterer, A. L., Aguin-Pombo, D., \& Franquinho-Aguiar, A. M. (2006). Long term impact of exotic ants on the native ants of Madeira. Ecological Entomology, 31: 358-368. 
Wetterer, J. K., Wild, A. L., Suarez, A. V., Roura-Pascual, N., \& Espadaler, X. (2009). World wide spread of the argentine ant, Linepithema humile (Hymenoptera: Formicidae). Myrmecological News, 12: 187-194.

Wild, A. (2004). Taxonomy and distribution of the argentine ant (Linepithema humile) (Hymenoptera: Formicidae). Annals of the Entomological Society of America, 97: 1204-1215.

Wilson, E. O. (1987). Causes of ecological success - the case of the ants, the 6th Tansley lecture. Journ. of Anim. Ecol., 56: 1-9.

\section{Citation:}

Slimani, S., Berrai, H., Meridji, R., Taheri, A., Dahmani, L., Chebli, A., Biche, M. (2020). New reports of the Argentine ant Linepithema humile (Mayr, (1868) (Hymenoptera: Formicidae) in Algeria. Ukrainian Journal of Ecology, 10 (5), 248-252. 